Original Research Paper

\title{
Isolation of Endophytic Fungi from Vitex trifolia L and Antagonism Test against Sclerotium rolfsii and pathogenic bacteria
}

\author{
Muhammad Hasan Basri ${ }^{1 *}$, Lalu Zulkifli ${ }^{1,2}$, Abdul Syukur ${ }^{1,2}$ \\ ${ }^{1}$ Program Studi Magister Pendidikan IPA Universitas Mataram, Mataram, Indonesia. \\ ${ }^{2}$ Program Studi Pendidikan Biologi FKIP Universitas Mataram, Mataram, Indonesia.
}

\author{
Article History \\ Received : December $30^{\text {th }}, 2020$ \\ Revised : January $07^{\text {th }}, 2021$ \\ Accepted : January $17^{\text {th }}, 2021$ \\ Published : January $20^{\text {th }}, 2021$ \\ *Corresponding Author: \\ Muhammad Hasan Basri \\ Program Studi Magister \\ Pendidikan IPA Universitas \\ Mataram, Mataram, Indonesia; \\ Email: \\ m.hasanbasri@unram.ac.id
}

\begin{abstract}
Plant damage by pathogenic fungi is often found in plants, one of which is caused by Sclerotium rolfsii. Biological control strategy offers a promising alternative for managing disease in plants because they are environmental friendly compared to pesticides application. One of the biological control offered is by using endophytic fungi isolated from Vitex trivolia $\mathrm{L}$. The aim of the study was to isolate, to identify macroscopic and microscopic endophytic fungi from Vitex trifolia $\mathrm{L}$ and to test their antagonism potency against the pathogenic fungus Sclerotium rolfsii in vitro. The isolation obtained 7 endophytic fungi isolates identified based on their genus characteristics, nsmely Periconia sp, Aspergillussp, Dendrophoma sp, Geotrichum sp, Ampulliferina sp, Chalara sp, dan Bispora sp and 2 isolates have not been identified. The Antibacterial test of the fungi isolate on the 4 tested bacteria showed that of all the fungi isolate have low activity. The antagonism test using the direct opposition method with the PIRG formula, showed that the 3 isolates had high percentage of growth inhibition, in which ALJ1, BLJ5, and ALJ3 isolate has $85 \%, 90 \%$, and 100\% respectively. This potency could be used as biological agents on the pathogenic fungus Sclerotium rolfsii.
\end{abstract}

Keywords: Vitex trifolia L, PIRG, Endophytic fungi, Sclerotium rolfsii.

\section{Pendahuluan}

Pencarian sumber senyawa bioaktif terus menerus dilakukan seiring dengan makin banyaknya penyakit-penyakit baru yang bermunculan, mulai dari penyakit infeksi, kanker, dan beberapa penyakit berbahaya lainnya. Senyawa bioaktif dapat diperoleh dari beberapa sumber, diantaranya dari tumbuhan, hewan, mikroba dan organisme laut. Salah satu sumber senyawa bioaktif yang dewasa ini menjadi populer adalah yang berasal dari mikroba. Salah satu mikroba penghasil senyawa bioaktif adalah jamur endofit yang merupakan jamur yang tumbuh dan mengkolonisasi di jaringan tumbuhan (inang) terutama di bagian akar, batang dan daun. Jamur endofit dapat menghasilkan senyawa-senyawa bioaktif dan metabolit sekunder yang sama dengan inangnya. Hal ini diduga karena jamur endofit mengalami koevolusi transfer genetik dari inangnya (Hasiani, 2015).

Mikroorganisme endofitik adalah mikroorganisme yang hidup dan berasosiasi di dalam jaringan tanaman inang. Asosiasi yang terjadi umumnya bersifat mutualisme. Kemampuan mikroorganisme endofitik memproduksi senyawa metabolit sekunder sesuai dengan tanaman inangnya merupakan peluang yang sangat baik (Petrini et al., 1992) dalam Sulistiyono dan Mahyuni (2019). Mikroba endofit memiliki peran penting terhadap jaringan tanaman inang. Sifat mikroba endofit menunjukkan adanya hubungan simbiosis mutualisme dengan tanaman inangnya. Mikroba endofit dalam jaringan tanaman mampu menghasilkan senyawa khusus yang mirip dan memiliki aktivitas biologis yang sama dengan inangnya (Septiana, 2017). Mikroba endofit baik bakteri maupun jamur memiliki potensi sebagai agen pengendali hayati karena memiliki sifat antagonistik dengan menghasilkan enzim yang selanjutnya berperan dalam pengendalian patogen. Jamur endofit Trichoderma spp. isolat lokal NTB menunjukkan aktivitas penghambatan terhadap pertumbuhan Fusarium oxysporum f.sp vanillae secara in-vitro (Sudantha dan Abadi, 
2011). Mikroba endofit memiliki potensi tidak terbatas dan penting secara ekonomis dalam berbagai bidang industri karena bermanfaat sebagai sumber bahan baku obat yang alami. Endofit memproduksi senyawa metabolit sekunder sehingga mampu memberikan pertahanan diri dan perlindungan bagi tanaman inang. Mikroba endofit yang diisolasi dapat digunakan sebagai antikanker, antibiotik, imunosuspresan dan anti jamur (Strobel dan Daisy, 2004).

Kandungan dari Vitex trifolia telah dilaporkan dalam beberapa penelitian. Aditya dan Kumar (2014) melaporkan bahwa ekstrak etanol daun Vitex trifolia terdapat senyawa metabolit sekunder antara lain alkaloid, saponin, flavonoid, karbohidrat dan antrakuinon glikosida. Mary et al. (2014) juga melaporkan berdasarkan analisis kualitatif dari daun Vitex trifolia dengan metode standar menggunakan pelarut petrolium ether, benzena, aceton, etanol dan air menunjukkan adanya kandungan alkaloid, saponin, tanin, fenol, terpenoid, flavonoid, dan steroid. (Maia, 2011) melaporkan juga bahwa daun legundi mengandung beberapa senyawa aktif yang memiliki aktivitas penolak nyamuk (repellent) seperti champene, pinene, alkaloid, terpenoid, saponin, dan sineol. Senyawa antimikroba dalam tumbuhan tidak hanya dihasilkan oleh tumbuhan langsung melainkan dapat dihasilkan oleh hampir semua jenis makhluk hidup termasuk mikroba endofit (Berdy, 2005). Mikroba endofit merupakan semua mikroorganisme yang menghuni bagian dalam tanaman terutama daun, batang, dan akar serta tidak menunjukkan aktivitas yang berbahaya bagi tanaman inangnya (Azevedo et al., 2000).Mikroba endofit dapat berupa bakteri maupun jamur.

Sclerotium rolfsii merupakan jamur patogen penyebab busuk akar, busuk batang, dan layu pada lebih dari 500 jenis tumbuhan, termasuk hampir semua tanaman pertanian. Jamur ini ditularkan melalui tanah yang biasanya terjadi di daerah tropis, subtropis dan daerah beriklim hangat lainnya di dunia (Yaqub, 2005). Salah satunya dapat menyebabkan penyakit busuk batang pada tanaman kacang tanah (Prasati, 2013) akibatnya produktivitas hasil panennya menurun, Buhaira, 2009 dalam prasati (2013) menyebutkan pada daun yang letaknya dekat dengan tanah jamur membentuk bercakbercak berwarna coklat muda dengan cincin sepusat berwarna gelap, garis tengah $2 \mathrm{~cm}$, di tengah-tengah bercak pada sisi bawah daun biasanya terdapat sclerotia berwarna coklat muda. Penyakit yang disebabkan oleh $S$. rolfsii ditanggulangi menggunakan pestisida yaitu golongan fungisida sintetis atau kimiawi. Penggunaan fungisida sintetis atau kimiawi secara terus-menerus dalam kegiatan pertanian dapat mengakibatkan dampak negatif pada kesehatan manusia karena terdapat residu pestisida pada produk makanan (Sofia, 2001). Oleh karena itu, dengan mengingat dampak dari pestisida kimia tersebut, perlu dipikirkan cara pengendalian yang aman bagi lingkungan, (Tenrirawe, 2008). Salah satu alternatif pengendalian adalah secara hayati menggunakan jamur endofit yang bersifat antagonistik (Sudantha dan Abadi, 2007) yang diisolasi dari tumbuhan Vitex trifolia L.

Berkaitan dengan potensi tumbuhan Vitex trifolia L dijadikan sebagai bahan baku obat dan kandungan metabolit sekundernya. Oleh karena itu, perlu juga dilakukan penelitian tentang identifikasi jamur endofitnya serta kemampuan dan potensi jamur endofitnya sebagai agen hayati sebagai antijamur dan antibakteri

Tujuan dari penelitian ini adalah untuk mengidentifikasi jamur endofit hasil isolasi dan menemukan aktivitas antijamur dan antibakterinya berdasarkan zona hambatnya..

\section{Bahan dan Metode}

Bahan yang diperlukan dalam penelitian adalah akar, batang dan daun legundi, jamur uji Sclerotium rolfsii, Potato Dextrose Agar (PDA), Nutrient Agar (NA), Mueller Hinton Agar (MHA), Potato Dextrose Yeast (PDY), spiritus, aquades, alkohol $70 \%$, tissue, sodium hypoclorite $5 \%$, ciprofloxacin, bakteri Uji S. aureus, B. cereus, E. coli dan P. auroginosa.

Jenis penelitian ini merupakan eksperimental laboratorium, uji antagonisme menggunakan metode oposisi langsung, yaitu menanam isolat endofit berseberangan dengan isolat patogen pada media PDA (Rahman et al., 2009). Uji daya hambat isolat jamur endofit terhadap bakteri uji isolat klinis menggunakan metode sumuran (Maulani et al, 2019).

\section{Isolasi Jamur Endofit}

Isolasi jamur endofit dilakukan dengan metode tanam langsung, yaitu setelah sampel dicuci aquades, direndam etanol $70 \%$ selama 30 detik, larutan $\mathrm{NaOCl}$ selama 3 menit dan perendaman terakhir menggunakan etanol $70 \%$ selama 1 menit. Selanjutnya potongan sampel 
dikeringkan di atas kaca yang steril selama beberapa menit. Masing-masing sampel dipotong kecil dan lapisan atas dikerik dengan pisau steril kemudian diletakkan di atas media PDAC (Potato Dextrose Agar Ciprofloxacin) yang telah ditambahkan dengan posisi permukaan belahan telah dikerik menempel pada agar media. Sampel diletakkan di atas medium dengan diberi tekanan, dan bagian potongan berada di atas medium. Inokulasi sampel dilakukan diatas cawan petri dan dilakukan triplo, tiap cawan berisi 3 potongan sampel. Selama pekerjaan dilakukan di dalam laminar air flow, dan kemudian diinkubasi selama 2-7 hari pada suhu ruang. Isolat endofit yang menunjukkan sifat morfologi jamur dipindahkan ke media PDAC yang baru.

\section{Pemurnian Jamur Endofit}

Jamur endofit yang telah tumbuh pada media isolasi PDAC, kemudian secara bertahap dimurnikan satu persatu. Masing-masing isolat murni jamur endofit yang diperoleh, kemudian dipindahkan ke dalam media dalam PDAC cawan Petri. Pemurnian ini bertujuan untuk memisahkan koloni endofit dengan morfologi berbeda untuk dijadikan isolat tersendiri. Pengamatan morfologi dilakukan kembali setelah inkubasi selama 5-7 hari, dan apabila masih ditemukan pertumbuhan koloni yang berbeda secara makroskopik maka harus dipisahkan kembali sampai diperoleh isolat murni. Jamur endofit diinkubasi pada suhu kamar selama 3-5 hari sesuai dengan pertumbuhannya.

\section{Identifikasi Jamur Endofit}

Identifikasi jamur endofit dilakukan dengan pengamatan secara makroskopis dan mikroskopis. Pengamatan makroskopis dengan cara melihat langsung warna koloni, warna sebalik koloni, dan pola penyebaran koloni jamur endofit. Pengamatan ciri mikroskopis meliputi ada tidaknya spora atau konidia, tipe hifa, bentuk spora dan konidia dengan menggunakan mikroskop. Identifikasi jamur endofit dilakukan berdasarkan buku identifikasi Burneet dan Hunter (Gandjar et al., 1999).

\section{Pembuatan Preparat dan Pengecatan Jamur}

Proses identifikasi jamur endofit dilakukan dengan pembuatan preparat dan pengecatan jamur sebelum diamati secara mikroskopis. Jamur yang akan diamati, diambil menggunakan jarum ent kemudian diletakkan diatas kaca preparat yang telah ditetesi pewarna Lacto cotton blue sebanyak 1 tetes. Jamur yang telah diberi pewarna pada kaca preparat selanjutnya ditutup dengan kaca objek/benda, kemudian diamati dibawah mikroskop. Kegiatan pembuatan preparat dan pewarnaan jamur dilakukan di dalam Laminar Air Flow untuk menghindari kontaminan (Suryaningsih \& Hadisoeganda, 2012).

\section{Uji antagonisme}

Isolat jamur endofit yang sudah dimurnikan selanjutnya diuji antagonismenya terhadap Sclerotium rolfsii. Uji antagonisme menggunakan metode oposisi langsung, yaitu menanam isolat endofit berseberangan dengan isolat patogen pada media PDAC (isolat patogen pada bagian pinggir media dan isolat endofit pada bagian tepi media yang lain). Cawan petri yang mengandung isolat jamur endofit dan Sclerotium rolfsii diinkubasi pada suhu ruang. Pengamatan dilakukan terhadap daya hambat isolat jamur endofit terhadap pertumbuhan patogen dan mekanisme penghambatan $S$. rolfsii oleh jamur endofit. Penghambatan pertumbuhan patogen diketahui dengan menghitung PIRG (Percentage Inhibition of Radial Growth (Rahmanet al., 2009) dengan formula:

$\mathrm{P}=\frac{r 1-r 2}{r 1} x 100 \%$, dimana $\mathrm{P}=\mathrm{PIRG}$ (persen hambat pertumbuhan), $\mathrm{r} 1=$ jari-jari patogen pada cawan control (tanpa isolate endofit) dan $\mathrm{r} 2=$ jari-jari pertumbuhan isolate patogen yang mengarah ke isolat jamur endofit pada cawan perlakuan. Pengukuran dilakukan ketika ujung hifa patogen yang tidak mengarah ke isolat jamur endofit mencapai pinggir cawan petri.

\section{Regenerasi Bakteri uji}

Bakteri uji S.aureus, B. cereus, E. coli dan P.auroginosa yang akan diujikan, terlebih dahulu harus diregenerasikan. Hal pertama yang dilakukan yaitu membuat media miring Nutrien Agar (NA). Media NA dituangkan ke dalam tabung reaksi, kemudian diletakkan pada posisi miring dan didiamkan hingga agar memadat. Selanjutnya menggoreskan biakan dari stok bakteri ke dalam agar miring Nutrien Agar (NA). Kultur bakteri pada masing-masing agar miring diinkubasi pada suhu $37^{\circ} \mathrm{C}$ selama $18-24$ jam (Iien et al., 2020).

\section{Suspensi Bakteri}

Suspensi bakteri dilakukan dengan cara bakteri uji yang telah diregenerasi diambil dengan jarum ose lalu disuspensikan ke dalam tabung reaksi berisi $5 \mathrm{~mL}$ larutan $\mathrm{NaCL}$ steril 
$0,9 \%$. Suspensi yang terbentuk disetarakan kekeruhannya dengan larutan standar Mc farlan 0,5 .

\section{Uji antibakteri}

Isolat jamur endofit yang sudah dimurnikan kemudian difermentasi dengan menggunakan media PDY yang bertujuan untuk memperoleh senyawa metabolit sekunder dari isolat jamur endofit. Koloni jamur endofit pada PDA diambil sekitar $\pm 1 \times 1 \mathrm{~cm}$ kemudian diinokulasikan ke dalam media PDY sebanyak $20 \mathrm{~mL}$ dalam labu erlenmeyer, kemudian difermentasi goyang menggunkan shaker dengan kecepatan $130 \mathrm{rpm}$ pada suhu ruang selama 6 hari. Setelah itu, medium cair hasil fermentasi dimasukkan ke dalam tabung sentrifuge, ditimbang, kemudian disentrifugasi dengan kecepatan $5000 \mathrm{rpm}$ selama 20 menit. Supernatan hasil sentrifugasi diambil, dan supernatan inilah yang digunakan untuk uji antimikroba terhadap bakteri isolat klinis dengan metode sumuran.

\section{Hasil dan Pembahasan}

\section{Hasil Identifikasi morfologi makroskopis dan} mikroskopis jamur endofit tumbuhan Vitex trivolia $\mathbf{L}$

Hasil pengamatan karakteristik makroskopik berdasarkan warna koloni, warna sebalik koloni, dan pola penyebaran koloni jamur endofit selama 7 hari setelah inkubasi menunjukkan warna koloni, warna sebalik koloni dan pola penyebaran koloni yang berbeda-beda tiap koloni jamur endofit. Hasil isolasi jamur endofit dari jaringan akar, batang dan daun legundi diperoleh 10 isolat meliputi 4 isolat dari akar, 5 isolat dari batang dan 1 isolat dari daun. Hasil pengamatan karakteristik makroskopis dan mikroskopis sebagai berikut:

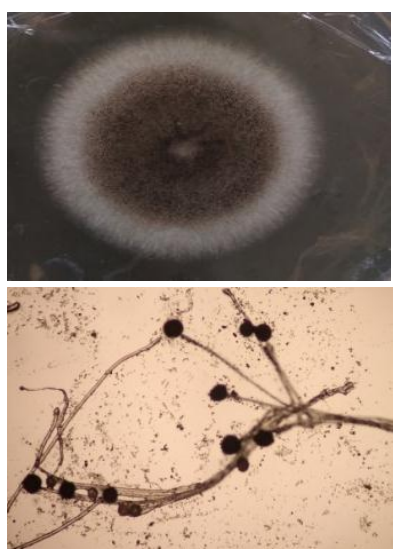

A

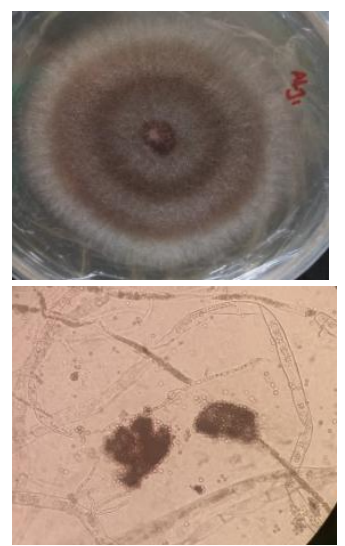

B

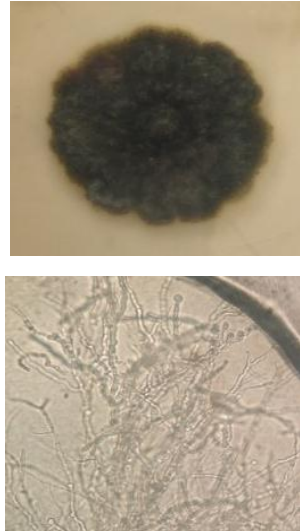

C

Gambar 1. Karakteristik Makroskopis dan Mikroskopis beberapa isolat BLJ1 (A), ALJ1 (B), dan DLJ1 (C)

Tabel 1. Karakteristik morfologi jamur endofit secara makroskopis dan mikroskopis

\begin{tabular}{|c|c|c|c|c|c|c|}
\hline \multirow{2}{*}{$\begin{array}{l}\text { Kode } \\
\text { isolat }\end{array}$} & \multicolumn{3}{|c|}{ Karakteristik makroskopis } & \multicolumn{3}{|c|}{ Karakteristik mikroskopis } \\
\hline & Warna koloni & $\begin{array}{l}\text { Warna dasar } \\
\text { koloni }\end{array}$ & $\begin{array}{l}\text { Pola } \\
\text { penyebaran }\end{array}$ & $\begin{array}{l}\text { Keberadaa } \\
\text { n spora }\end{array}$ & $\begin{array}{l}\text { Tipe } \\
\text { hifa }\end{array}$ & $\begin{array}{l}\text { Bentuk } \\
\text { spora }\end{array}$ \\
\hline BLJ1 & $\begin{array}{l}\text { Putih halus } \\
\text { tengah hitam }\end{array}$ & Putih & $\begin{array}{ll}\text { Bundar } & \text { ke } \\
\text { samping }\end{array}$ & Ada & Aseptat & Oval \\
\hline ALJ2 & $\begin{array}{l}\text { putih halus } \\
\text { tengah hitam }\end{array}$ & Putih & $\begin{array}{l}\text { Bundar } \\
\text { samping }\end{array}$ & Ada & Septat & Oval \\
\hline ALJ1 & $\begin{array}{l}\text { Putih halus } \\
\text { tengah hitam }\end{array}$ & Putih & $\begin{array}{l}\text { Bundar } \\
\text { samping }\end{array}$ & Ada & Septat & Oval \\
\hline BLJ2 & $\begin{array}{l}\text { Kuning kasar } \\
\text { kecoklatan }\end{array}$ & $\begin{array}{l}\text { Coklat } \\
\text { kehitaman }\end{array}$ & $\begin{array}{l}\text { Tidak } \\
\text { beraturan } \\
\text { samping }\end{array}$ & Ada & Septat & Oval \\
\hline DLJ1 & $\begin{array}{l}\text { Hitam } \\
\text { kehijauan } \\
\text { kasar }\end{array}$ & Hitam & $\begin{array}{l}\text { Tidak } \\
\text { beraturan } \\
\text { samping }\end{array}$ & Tidak ada & Septat & - \\
\hline
\end{tabular}




\begin{tabular}{llllllll}
\hline ALJ3 & $\begin{array}{l}\text { Putih kasar } \\
\text { bagian atas } \\
\text { merah cair }\end{array}$ & $\begin{array}{l}\text { Merah } \\
\text { dengan } \\
\text { pinggir putih }\end{array}$ & $\begin{array}{l}\text { Tidak } \\
\text { beraturan } \\
\text { samping }\end{array}$ & ke & Ada & Septat & Oval \\
\hline ALJ4 & Hitam halus & Hitam & $\begin{array}{l}\text { Bundar } \\
\text { samping }\end{array}$ & ke & Ada & Septat & Oval \\
\hline BLJ6 & Putih halus & Putih & $\begin{array}{l}\text { Bundar } \\
\text { samping }\end{array}$ & ke & Tidak ada & Septat & - \\
\hline BLJ3 & $\begin{array}{l}\text { Putih } \\
\text { kecoklatan } \\
\text { kasar }\end{array}$ & Cokelat & $\begin{array}{l}\text { Tidak } \\
\text { beraturan } \\
\text { samping }\end{array}$ & ke & Ada & Septat & Oval \\
\hline BLJ5 & Putih halus & Putih & $\begin{array}{l}\text { Bundar } \\
\text { samping }\end{array}$ & ke & Tidak ada & Septat & - \\
\hline
\end{tabular}

\section{Keterangan:}

ALJ : isolat jamur endofit akar

BLJ : isolat jamur endofit batang

DLJ : isolat jamur endofit daun

Tabel 2. Hasil identifikasi genus dari isolate jamur endofit tanaman $V$. trifolia

\begin{tabular}{|c|c|c|c|}
\hline $\begin{array}{l}\text { Kode } \\
\text { isolat }\end{array}$ & $\begin{array}{l}\text { Organ sumber } \\
\text { isolat }\end{array}$ & $\begin{array}{l}\text { Termasuk dalam } \\
\text { Genus }\end{array}$ & Referensi \\
\hline ALJ1 & akar & Aspergillus & Barnett and Hunter (1978) \\
\hline ALJ2 & akar & Aspergillus & Barnett and Hunter (1978) \\
\hline ALJ3 & akar & Ampulliferina & Barnett and Hunter (1978) \\
\hline ALJ4 & akar & Chalara & Barnett and Hunter (1978) \\
\hline BLJ1 & batang & Periconia & Barnett and Hunter (1978) \\
\hline BLJ2 & batang & Dendrophoma & Barnett and Hunter (1978) \\
\hline BLJ3 & batang & $\begin{array}{l}\text { Belum } \\
\text { teridentifikasi }\end{array}$ & \\
\hline BLJ5 & batang & Bispora & Watanabe (2002). \\
\hline BLJ6 & batang & $\begin{array}{l}\text { Belum } \\
\text { teridentifikasi }\end{array}$ & \\
\hline DLJ1 & daun & Geotrichum & Barnett and Hunter (1978) \\
\hline
\end{tabular}

\section{Hasil Uji antagonisme isolat jamur endofit Vitex trifolia $\mathrm{L}$ terhadap jamur patogen Sclerotium rolfsii}

Uji antagonisme merupakan uji untuk mengetahui kemampuan isolat jamur endofit
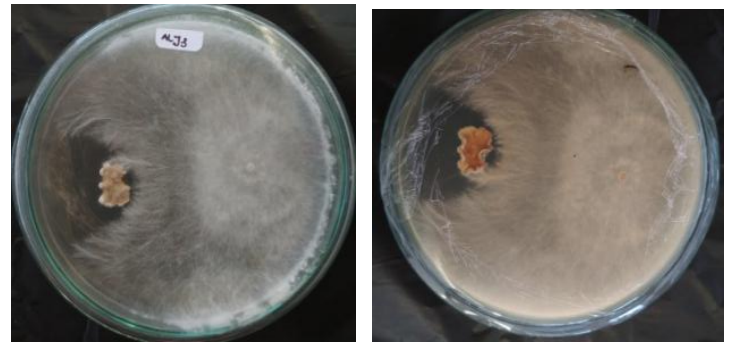

A
Vitex trifolia $\mathrm{L}$ dalam menekan pertumbuhan jamur patogen Sclerotium rolfsii pada media uji serta melihat mekanisme hambatnya terhadap jamur patogen itu sendiri. Berdasarkan hasil penelitian diperoleh hasil sebagai berikut:
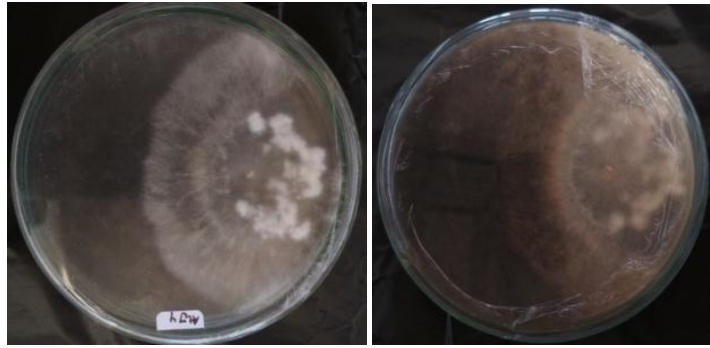

B

Gambar 2. Uji antagonisme isolat ALJ3 (A) dan ALJ4 (B) terhadap Sclerotium rolfsii dengan mekanisme Antibiotis (A) dan mekanisme Kompetisi (B) 
Tabel 2. Persentase daya hambat dan mekanisme isolat - isolat jamur endofit terhadap S. rolfsii

\begin{tabular}{llllll}
\hline No & Kode & Persen hambat $(\%)$ & \multicolumn{3}{c}{ Mekanisme } \\
\cline { 4 - 6 } & isolat & & antibiotis & Kompetisi & Mikoparasit \\
\hline 1 & BLJ1 & 32 & - & - & - \\
2 & ALJ2 & 55.5 & + & - & - \\
3 & ALJ1 & 85 & + & - & - \\
4 & BLJ2 & 44 & - & - & - \\
5 & DLJ1 & 52 & - & - & - \\
6 & ALJ3 & 100 & + & - & - \\
7 & ALJ4 & 72 & - & + & - \\
8 & BLJ6 & 22 & - & - & - \\
9 & BLJ3 & 41 & - & - & - \\
10 & BLJ5 & 90 & - & + & \\
\hline
\end{tabular}

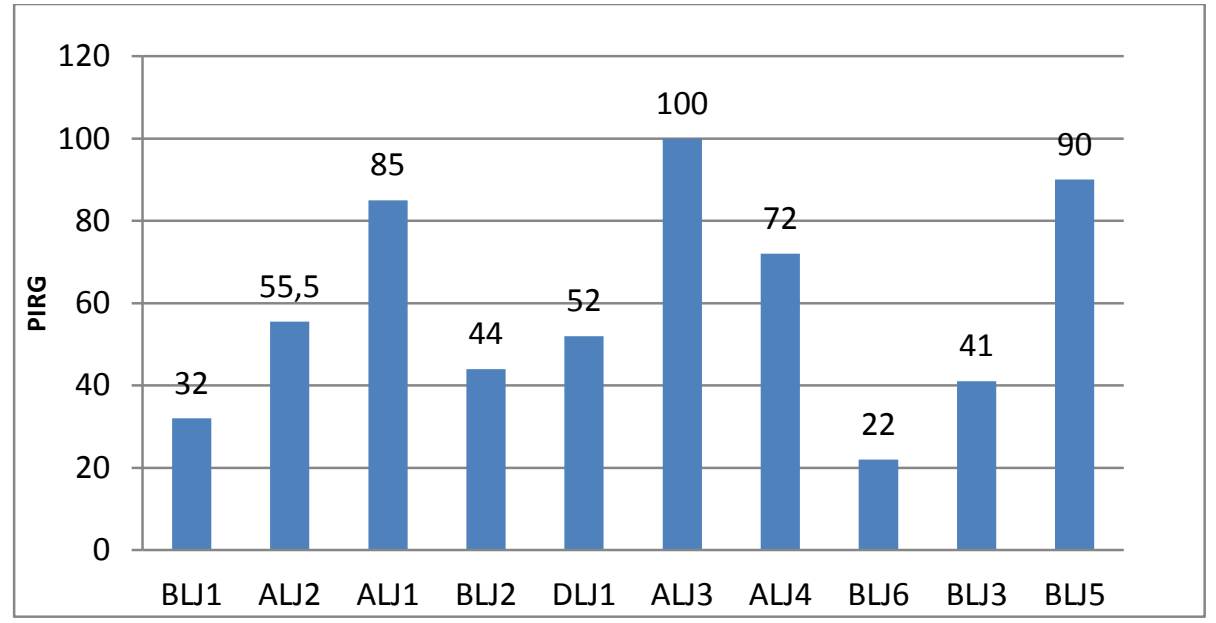

Gambar 3. Grafik PIRG (Persentage Inhibition of Radial Growth) atau persen hambat Isolat jamur endofit terhadap pertumbuhan jamur patogen $S$. rolfsii

Hasil Uji antibakteri isolat jamur endofit Vitex trifolia $\mathrm{L}$ terhadap bakteri isolat klinis

Hasil uji daya hambat isolat jamur endofit terhadap bakteri isolat klinis $S$. aureus, $B$. cereus, E. coli dan $P$. auroginosa menunjukkan bahwa semua isolate memiliki zona hambat yang lemah, semua di bawah $2 \mathrm{~mm}$ (data tidak ditampilkan).

Identifikasi morfologi makroskopis dan mikroskopis jamur endofit tumbuhan Vitex trivolia $\mathbf{L}$

Berdasarkan hasil identifikasi makroskopis dan mikroskopis isolat jamur endofit Vitex trifolia L diperoleh 10 isolat murni, ada 8 isolat teridentifikasi dan 2 isoalat belum teridentifikasi (Tabel 2.). Identifikasi ini mengacu kepada Barnet \& Hunter (1978) dan Watanabe (2002).
Uji antagonisme isolat jamur endofit Vitex trifolia $\mathbf{L}$ terhadap jamur patogen Sclerotium rolfsii

Selanjutnya isolat-isolat tersebut diuji secara in vitro terhadap perkembangan patogen $S$. rolfsii untuk mengetahui perbedaan daya hambat dari setiap isolat.Isolat yang memiliki dayahambat $\square \square 80 \%$ diasumsikan potensial sebagai sebagai agens hayati (Mulyani et al, 2018). Mikroba yang dapat dimanfaatkan sebagai agens hayati harus memiliki mekanisme antagonisme yang dapatmelemahkan atau mematikanpertumbuhan patogen secara langsung, memproduksi antibiotik (toksin) dan berkompetisi terhadap ruang dan nutrisi.Selain itu, kemampuan menghambat olehjamur rizosfer maupun endofit didasarkan pada kemampuannya memproduksi enzim pendegradasi dinding sel patogen (Arios et al, 2014).

Jamur antagonis yang memiliki daya 
hambat yang besar terhadap pertumbuhan jamur patogen memiliki luas pertumbuhan yang lebih besar dibanding dengan jamur yang mempunya daya hambat yang lebih kecil. Hal ini sesuai dengan Soesanto (2008) yang menyatakan bahwa agens hayati yang berbeda memiliki kemampuan dan mekanisme penghambatan yang berbeda.

Penghambatan jamur endofit terhadap $S$. rolfsii sangat bervariasi yang disebabkan oleh perbedaan mekanisme dari masing-masing isolat. Menurut Arnold et al., (2003), mekanisme penghambatan pertumbuhan patogen oleh jamur endofit dapat dengan memarasit patogen secara langsung, memproduksi antibiotik, kompetisi ruang dan nutrisi, produksi enzim, dan menginduksi respons ketahanan tanaman.

Hasil pengamatan daya hambat jamur endofit terhadap $S$. rolfsii secara in vitro memperlihatkan mekanisme yang bervariasi, yaitu kompetisi $(2$ isolat $=$ ALJ4 dan BLJ5) di mana persen hambat masing-masing adalah $72 \%$ dan $90 \%$, antibiotis (3 isolat $=$ ALJ2, ALJ1, dan ALJ3) dengan persentase hambat masing-masing adalah $55.5 \%, 85 \%$ dan $100 \%$ (Tabel 2 dan Gambar 3). Persentase hambat tertinggi dan memiliki kategori baik sebagai agen hayati adalah isolat ALJ3 persen hambatnya yaitu $100 \%$,itu ditandakan dengan adanya zona bening disekitar isolat endofitnya, terlihat dengan tidak disentuhnya isolat oleh miselium atau hifa jamur S. rolfsii selama 7 hari. Selanjutnya isolat BLJ5 persen hambatnya yaitu $90 \%$ terlihat dengan sedikitnya miselium $S$. rolfsi yang menyentuh bagian dari isolat selama 7 harihsi, dan isolat ALJ1 persen hambatnya yaitu $85 \%$ terlihat dengan mendominasinya miselium isolat ketimbang miselium jamur $S$. rolfsii. Besarnya persen hambat itu disebabkan oleh zat atau senyawa anti jamur yang dihasilkan oleh isolat ALJ3 yang dapat menghambat pertumbuhan fitopatogen melalui mekanisme aktivitas metabolit sekunder dan zat anti mikroba yang memiliki aktivitas antagonis (Kalay et al., 2018).

Kompetisi adalah pertumbuhan jamur endofit lebih cepat dibanding dengan pertumbuhan $S$. rolfsii sehingga semua ruang dipenuhi oleh jamur endofit dan pertumbuhan $S$. rolfsii terhambat. Mekanisme sntibiotis dapat menghambat patogen dengan cara menghasilkan antibiotik, enzim, dan toksin .Mekanisme penghambatan pertumbuhan $S$. rolfsii oleh jamur endofit secara antibiotisis dicirikan oleh zona bening di sekitar pertemuan jamur endofit dengan patogen. Mekanisme antibiosis dapat berupa produksi antibiotik atau sekresi enzim litik (Arnold et al., 2003). Jamur endofit dapat menghasilkan satu atau beberapa jenis antibiotik yang tergolong terpenoid, alkaloid, senyawa aromatik, dan polipeptida, seperti EtAOc dan $n$ butanol (Liu, Zou, Lu \& Tan 2001).

\section{Kesimpulan}

Hasil isolasi jamur endofit dari akar, batang dan daun Vitex trivolia $\mathrm{L}$ diperoleh 8 isolat jamur endofit teridentifikasi berdasarkan ciri genusnya ; Periconia sp, 2 Aspergillus sp, Dendrophoma sp, Geotrichum sp, Ampulliferina sp, Chalara sp, dan Bispora sp serta 2 isolat belum teridentifikasi. Berdasarkan Uji antagonisme menggunakan metode oposisi langsung dihitung dengan formula PIRG diperoleh 3 isolat tertinggi persen hambatnya yang bisa digunakan sebagai agen hayati; ALJ3 (100\%), BLJ5 (90\%) dan ALJ1 (85\%). Pada uji anti bakteri, zona hambat tertinggi pada bakteri $P$. aeuroginosa sebesar $1 \mathrm{~mm}$ dengan kategori lemah.

\section{Ucapan Terima Kasih}

Terimakasih kepada Direktorat Riset dan Pengabdian Masyarakat Kemenrsitek-Dikti atas dukungan pendanaan Melalui skema PTMKompetitif Nasional menurut kontrak Penelitian PTM No: 1679/UN18.L1/PP/2020.

\section{Referensi}

Hasiani, V. V., Ahmad, I., \& Rijai, L. (2015). Isolasi jamur endofit dan produksi metabolit sekunder antioksidan dari daun pacar (Lawsonia inermis L.). Jurnal Sains dan Kesehatan, 1(4), 146-153. https://jsk.farmasi.unmul.ac.id/index.php/ jsk/article/view/32

Sulistiyono, F. D., \& Mahyuni, S. (2019). Isolasi Dan Identifikasi Jamur Endofit Pada Umbi Talas (Colocasia esculenta (L.) Schoot). Jurnal Sains Natural, 9(2), 66-70. https://repository.unpak.ac.id/tukangna/re po/file/files-20201208112200.pdf

Septiana, E. (2017). Bakteri Endohifa: Si Kecil di Balik Besarnya Manfaat Kapang Endofit. Biotrends, 8(1), 10-16. file:///C:/Users/ASUS/Downloads/198363-1-SM.pdf 
Sudantha, I. M., \& Abadi, A. L. (2011). Uji Efektivitas Beberapa Jenis Jamur Endofit Trichoderma spp. Isolat Lokal NTB Jamur Fusarium oxysporum f.sp. vanillae Penyebab Penyakit Busuk pada Bibit vanili. Agroteksos,4(2): 64-73. DOI :https://scholar.google.co.id/citations?user $=$ dhVzR6gAAAAJ\&hl=id

Strobel, G., Daisy, B., Castillo, U., \& Harper, J. (2004). Natural products from endophytic microorganisms. Journal of Natural products, 67(2), 257-268. https://pubs.acs.org/doi/abs/10.1021/np03 $\underline{0397 \mathrm{v}}$

Aditya, K., \& Kumar, A. R. (2014). Phytochemical evaluation of Vitex leuocoxylon, vitex negundo and vitex trifolia. Indian Journal of Research in Pharmacy and Biotechnology, 2(2), 1106. https://www.ijrpb.com/issues/Volume\%2 02 Issue \%202/ijrpb\%202(2)\%206\%20K \%20Aditya1\%201106-1108.pdf

Mary, R. N. I., Meenashree, B., \& Vasanthi, V. J. (2014). Screening of antibacterial activity and qualitative and quantitative analysis of phytochemicals in Vitex trifolia. Int. J. Curr. Microbiol. Appl. Sci, 3, 425-431. https://www.researchgate.net/profile/Mee nashree_Balakrishnan/publication/325464 $\underline{368}$

Maia, M.F. \& Moore, S.J. (2011). Plant-Based Insect Repellents: A Review of Their Efficacy, Development and Testing. Malaria Journal. 10(Suppl 1):S11. DOI: https://www.researchgate.net/publication/ $\underline{50408598}$

Berdy, J. (2005). Review Article: Bioactive Microbial Metabolites. The Journal of Antibiotics, 58(1): 1-26. DOI :https://www.nature.com/articles/ja20051

Azevedo, J.L. Maccheroni, W. Pereira, J.O. \& Araujo, W.L.D. (2000). Endophytic Microorganism: A Review in Insect Control and Recent Advances on Tropical Plants. Electron Journal of Biotechnology, 3(1): 40-65. ISSN: 0717- 3458. DOI: http://www.bioline.org.br/pdf?ej00005
Yaqub, F. and Shahzad, S. (2005). Pathogenicity of Sclerotium rolfsii in different crops and effect of inoculums density on colonization of mungbean and sunflower roots. Pak J. Bot. 37(1): 175-180. DOI: https://www.researchgate.net/publication/ $\underline{266468138}$

Prasati, O.H., Kristanti, I., \& Nurhatika,S. (2013) Pengaruh Mikoriza Glomusfasciculatum Terhadap Pertumbuhan Vegetatif Tanaman Kacang Tanah yang Terinfeksi Patogen Sclerotiumrolfsii. Jurnal sains dan seni pomits. 2(2):74 - 78. DOI: http://ejurnal.its.ac.id/index.php/sains_sen $\mathrm{i} /$ article/view/3624

Sofia, D. (2001). Pengaruh Pestisida Dalam Lingkungan Pertanian. Sumatera Utara: USU. DOI: http://repository.usu.ac.id/handle/123456 $\underline{789 / 1106}$

Tenrirawe, A dan A.H. Talanca. 2008. Bioekologi dan Pengendalian Hama dan Penyakit Utama Kacang Tanah. Prosiding: 464 - 471.4 DOI: https://id.scribd.com/doc/75956645/54Tenrirawe-Pengendalian-Penyakit-Ktanah-464-471-2

Sudantha, I.M \& A.L Abadi (2007). Identifikasi Jamur Endofit dan Mekanisme Antagonismenya terhadap Jamur Fusarium oxysporum f. sp vanillae Pada Tanaman Vanili. Agroteksos. 17 (1). DOI: https://www.semanticscholar.org/paper/id entifikasi-jamur-endofit-dan-mekanismeterhadap-Sudantha-

Abadi/7228d53b821f48c5051f9dd950c9f 8210d8332e4

Gandjar, I. Samson, R. A., Van Den TweelVermeulen, K. Oetari, A. \& Santoso, I. (1999). Pengendalian Kapang Tropik Umum. Yayasan Obor Indonesia. Jakarta. ISBN 979-461-289-8

Suryaningsih, E \& W. Hadisoeganda (2012). Pestisida Botani untuk Mengendalikan Hama dan Penyakit pada Tanaman Sayuran. Bandung. Mitra Buana Pasundan

Rahman, M. A., Begum, M. F., \& Alam, M. F. (2009). Screening of Trichoderma isolates 
as a biological control agent against Ceratocystis paradoxa causing pineapple disease of sugarcane. Mycobiology, 37(4), 277-285.

DOI: https://doi.org/10.4489/MYCO.2009.37.4. 277

Iien, H., Zulkifli, L., \& Prapti, S. (2020). Aktivitas antibakteri ekstrak metanol daun turi (Sesbania grandifora L) terhadap pertumbuhan Klebsilla pneumonia. Jurnal Biologi Tropis, 20 (1): 219-225. DOI: http://dx.doi.org/10.29303/jbt.v20i2.1790

Barnett, H.L., and Hunter, B.B. (1978). Ilustrated Genera of Imperfect Fungi Fourth Edition. APS Press. Minnessota

Watanabe, S. (2002). Pictorial Atlas of Soil and Seed Fungi Morphologies of Cultured Fungi and Key to Species Second Edition. CRC Press. Washington, D.C. ISBN 08493-1118-7.

Mulyani, R. B., Usup, A., Supriati, L, \& Ramlan. (2018). Peran Agen Hayati Asal Rizosfer Dan Endofit Menekan PenyakitBusuk Sklerotium rolfsii Bawang Daun Di Media Gambut. Jurnal AGRI PEAT, 19 (2). ISSN: 1411 - 6782 (Cetak) 2620-6935 (Elektronik. DOI: https://ejournal.upr.ac.id/index.php/Agp/article/vi $\underline{\mathrm{ew} / 159}$

Arios, L. N., Kiki, K., Erman, M., \& Dwi, S. (2014). Asai kemampuan bakteri endofit dari kacang tanah dalam menghambat pertumbuhan sclerotium sp. Pada kecambah kacang tanah. Jurnal Hama dan
Penyakit Tumbuhan Tropika, 14(2). DOI: https://doi.org/10.23960/j.hptt.214178$\underline{186}$

Arnold, A.E, Mejia, L.C., Kyllo, D., Rojas, E.L, Maynard, Z., Robbins, N., \& Herre, E.A. (2003). Fungal endophytes limit pathogen damage in a tropical tree. PNAS, 100, 15649-15654.

DOI: https://doi.org/10.1073/pnas.2533483100

Kalay, A.M., Abraham, T., \& Wilhemina, R. (2018). Uji Antagonisme Trichodermaharzianum dan Azotobacterchroococcum terhadap Rhyzoctoniasolani, Sclerotiumrolfsii dan FusariumOxysporum Secara in-Vitro. Agrogolia, $\quad 7(2) . \quad$ DOI: http://dx.doi.org/10.30598/a.v7i2.764

Liu, C.H., Zou, W.X., Lu, H., \& Tan, R.X. (2001). Antifungal Activity of Artemisia annua endophyte cultures against phytopathogenic fungi. J Biotechnol, 88, 277-282.

DOI: https://doi.org/10.1016/S01681656(01)00285-1

Maulani, B. I. G., Rasmi, D. A. C., \& Zulkifli, L. (2019). Isolation and characterization of endophytic bacteria from mangrove Rhizophora mucronata Lam. and antibacterial activity test against some pathogenic bacteria. In Journal of Physics: Conference Series, 1402 (3), p. 033038. IOP Publishing. https://iopscience.iop.org/article/10.1088/ $\underline{1742-6596 / 1402 / 3 / 033038}$ 